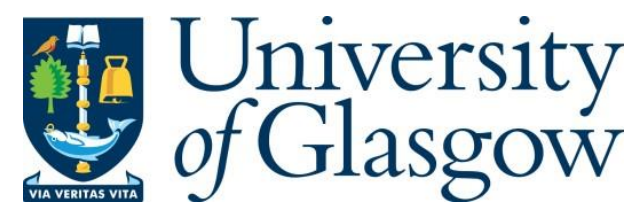

Roy, G. and Spowage, M. (2021) Government Expenditure and Revenue Scotland (GERS): a look beyond nearly 30 years of controversy at what it does and doesn't tell us about Scotland. Scottish Affairs, 30(4), pp. 423-449.

There may be differences between this version and the published version. You are advised to consult the publisher's version if you wish to cite from it.

https://eprints.gla.ac.uk/262481/

Deposited on: 7 January 2022

Enlighten - Research publications by members of the University of Glasgow https://eprints.gla.ac.uk 
This is a peer-reviewed, accepted author manuscript of the following research article: Roy, G., \& Spowage,

M. (2021). Government expenditure and revenue Scotland (GERS): a look beyond nearly 30 years of controversy at what it

does and doesn't tell us about Scotland. Scottish Affairs, 30(4), 423-449. https://doi.org/10.3366/scot.2021.0383

\title{
Government Expenditure and Revenue Scotland (GERS): A look beyond nearly 30 years of controversy at what it does and doesn't tell us about Scotland \\ Graeme Roy and Mairi Spowage
}

\begin{abstract}
Government Expenditure Revenue Scotland (GERS) remains a controversial statistical publication on Scotland's public finances. We trace the evolution of GERS over time, and track how it has been used in political debate since it was first published in 1992. Now in its $27^{\text {th }}$ edition, we review its ongoing role in informing constitutional and fiscal debate in Scotland. We dispel some of the myths about the publication, but also highlight legitimate criticisms, and explore how it is used by both sides in the independence debate. Our main contribution is to summarise what GERS tells us - and crucially what it does not tell us about the state of Scotland's economy and public finances. We conclude with an assessment of what GERS might tell us about the prospects for any future debate on Scottish independence.
\end{abstract}

Keywords: GERS, Budget, Taxation, Public Spending, Independence, North Sea oil

Graeme Roy is Professor of Economics and Dean of External Engagement at the College of Social Sciences, University of Glasgow; Mairi Spowage is Director of the Fraser of Allander Institute, University of Strathclyde. Both have written extensively on the Scottish economy. Both were civil servants in the Scottish Government with responsibility for the production of the GERS report - Graeme as Head as a Senior Civil Servant \& Head of the Office of the Chief Economic Adviser, and Mairi as the Senior Statistician responsible for National Accounts. 


\section{Introduction}

It is hard to think of a statistical publication that generates more controversy than Government Expenditure Revenue Scotland (GERS). GERS is the annual statistical publication - published by the Scottish Government - that provides an estimated set of public sector finance accounts for Scotland. 2020 saw the 27th edition published, having been first published in 1992. The publication attracts significant political comment and media attention. It is not difficult to appreciate why. The question of Scotland's fiscal prospects, from the It's Scotland's Oil campaign in the 1970s, has dominated the independence and wider constitutional debate for over five decades. But behind all of this controversy is a statistical publication that contains useful insights about the sustainability of public services in Scotland, what we spend our taxes upon, and who bears the burden of these taxes. It has also helped to shape the design of devolution in Scotland, from 1999 through to the 2016 Scotland Act. At the same time, GERS does provide important insights about the finances of a future independent Scotland. By definition, a set of accounts based upon the status quo, does not say anything about the long-term opportunities, challenges or choices that an independent Scotland would face. But it does provide a useful illustration of the 'starting point'. It requires those proposing alternative constitutional futures, from further devolution through to independence, to set out the choices and plans that they would make.

The aim of this article is to shed some light on the GERS report. In doing so, we provide both a historical review and up-to-date perspective on the public finance debate in Scotland. We review its origins and evolution. We discuss its methods, strengths and limitations. The authors are grateful for the insights of current and former civil servants for their insights and comments on this paper.

\section{What is GERS?}

'The aim of GERS is to enhance public understanding of fiscal issues in Scotland' (Scottish Government, 2020). ${ }^{1}$

In short, GERS aims to provide estimated annual set of fiscal accounts for Scotland, and in doing so to look at both spending and revenue aspects of the public sector ${ }^{2}$. It includes both Scottish Government and local government spending and tax revenues, but also UK Government spending and taxes spent for and raised on behalf of the people of Scotland. It is backward looking, with the latest year (at the time of writing) up to the 2019/20 financial

\footnotetext{
${ }^{1}$ The GERS pages on the Scottish Government website contains a discussion of methodologies and approaches used in the report - https://www.gov.scot/publications/about-government-expenditure-and-revenue-scotland/ 2 Until 2000, GERS focussed only upon General Government activities rather than all activities of the public sector. That is, it did not include the activities of public corporations (e.g. Scottish Water).
} 
year, and therefore takes the current constitutional settlement - and the policy choices of the relevant governments in power - as given at each point in time. (Scottish Government, 2020)

GERS is not a set of audited financial accounts as many would perhaps believe. Why? Under the current constitutional settlement there is no 'one' government responsible for all public sector activity in Scotland. Nor is there a set of income and expenditure accounts that track all revenues collected from people in Scotland and monies spent. Instead, GERS provides a consolidated set of estimated spending and revenue figures covering all relevant aspects of government activity. It aims to do this in a way which is consistent with international standards on the production of public sector finances, so that the estimates can be compared with the UK and other countries.

This immediately brings two key issues to the fore which are important to understand. The first is that GERS covers all aspects of public sector spending for Scotland, irrespective of which tier of government actually spends the money. The key source of this is the Public Expenditure Statistical Analyses report (HMT 2020), published each year by HM Treasury (more of this later). In GERS, the allocation of public sector expenditure is based on the 'who benefits' principle. That is, where is the measurable first-order benefit to society of a particular element of public expenditure? Based upon this approach there are two classifications of spending: 'identifiable' and 'non-identifiable' expenditure.

Identifiable expenditure is public sector spending that can be easily identified as having been spent for the benefit of someone living/working in a particular devolved nation or English region. Examples include: spending on schools, a public sector R\&D grant for a business located in Aberdeen, or the state pension of someone living in Edinburgh. This covers the vast majority - around $84 \%$ - of public spending in GERS.

Non-identifiable expenditure is trickier. This is expenditure that is not spent for the unique benefit of someone in a particular part of the UK, but for the benefit of everyone in the UK. Foreign aid is an uncontroversial example. Clearly it is not spent on activities within a particular part of the UK or for one person living in the UK; instead it is part of the UK's contribution to tackling global poverty and inequality. But others are more controversial. For example, defence expenditure is non-identifiable, on the assumption that everyone in the UK benefits on an equal basis from the security that this provides. But many of the impacts of defence spending have particular benefits (and costs) in certain parts of the UK - e.g. from the location of military bases through to the local jobs created from defence contracts (e.g. at 
Rosyth for the building of the two Queen Elizabeth class aircraft carriers or Barrow-in-Furness for the BAE systems submarine yard) ${ }^{3}$.

The second issue is that GERS attempts to measure public sector revenues 'paid' by taxpayers in Scotland, irrespective of who the tax is paid to. For some taxes, such as income tax and council tax, it is relatively straightforward to identify 'who pays' ${ }^{4}$. These taxes are particularly post tax devolution - easy to identify as having been raised from Scottish taxpayers ${ }^{5}$. But for many taxes, from VAT through to corporation taxes, there is simply no collection of data by each UK locality. For example, a business in the UK pays tax to HMRC based upon the profits it makes on its UK (and indeed, depending on their structures, its worldwide) activities, not on how much profit they made in a particular part of the UK. For the revenues where Scotland-specific outturn data is not available, GERS estimates Scotland's share of UK data. A variety of different methods are used ${ }^{6}$.

Combining these two elements, expenditure and revenue, gives rise to an estimated 'net fiscal balance' figure. If expenditures are higher than revenues, then Scotland is in an estimated net fiscal deficit. If revenues are higher than expenditures, then Scotland is in an estimated net fiscal surplus. It is this one figure that each year gives rise to significant controversy, although interestingly the first GERS publication in 1992 did not feature this number (Scottish Office, 1992)

\section{The political history of GERS}

GERS was first published in 1992. From day 1, a number of controversies surrounded its genesis and the motivation for publication. These range from the humorous - such as the rumour within the civil service that the name GERS was coined by a Rangers-supporting civil servant! - through to serious discussions around the constitutional status of Scotland. GERS was first published at a time of significant political debate and growing momentum for

\footnotetext{
${ }^{3}$ At the heart of this issue is the distinction between 'in' and 'for'. For many elements of spend, such as school education and health, there is no distinction. Spending is 'for' an individual living 'in' a particular area. But for things like defence where there is clearly spending 'in' an area, the benefit 'for' might take place both inside and outside the area in question.

${ }^{4}$ Corresponding to the 'who benefits' principle is the 'who pays' principle, which concerns the identification of the location of the source of public sector revenue. In GERS, the 'who pays' principle is based upon the residential location of where the revenue is raised.

${ }^{5}$ At first glance, it may seem odd that GERS allocates spending on the 'for' principle but revenue on the 'in' principle. But this is consistent with National Accounts practices. For example, if the UK spends money on foreign aid this will generate tax revenue for the country in which such spend takes place, even though the expenditure on aid is UK Government spend.

${ }^{6}$ These include surveys on consumer spending and regional accounts data from the ONS, transport data from the Department of Transport, and North Sea activity data now from HMRC (albeit in the past from Professor Alex Kemp at Aberdeen (Kemp and Stephen, 2008)).
} 
constitutional change in Scotland (Brown, 2000). In 1988, 'A Claim of Right for Scotland' had been published, leading to the establishment of the Scottish Constitutional Convention in March 1989. On St Andrews Day 1990, the Convention presented its report to the Scottish people Towards Scotland's Parliament setting out a broad framework for devolution.

In 1992, the Conservative Party won a hotly contested UK General Election, taking 11 out of 72 seats in Scotland (Butler \& Kavanagh, 1992) on a ticket of open hostility to devolution. But although they won a record fourth term of office in the UK, this victory arguably only strengthened the political determination of those in favour of a Scottish Parliament fuelled by a perception of a democratic deficit (Mitchell, 2009).

Labour and the Liberal Democrats (who together won 58 seats in Scotland in 1992 - with $52 \%$ of the vote) were both members of the Scottish Constitutional Convention. The SNP, despite a disappointing election in terms of seats, still took over $21 \%$ of votes cast. With momentum building for the creation of a Scottish Parliament, the Conservative Party and the Scottish Office were increasingly isolated on devolution (Mitchell op cit). Their strategy in response had a number of strands, including raising the prospect of the very stability of the UK being under threat. But the key element of their strategy, was to make the case that Scotland got a 'good deal' from the status quo, and any attempt to create a new parliament would put this at risk.

It is within this context that GERS was conceived. At this point in time, the UK Government did not regularly publish spending figures for each part of the UK or equivalent revenues ${ }^{7}$. So, by setting out Scotland's relatively higher spending per head compared to other parts of the UK, coupled with revenues lower than the UK average, Scottish Office Ministers hoped that when facing what they saw as the financial reality of devolution, voters would reject it.

In a now well-known leaked memo to the Prime Minister John Major on 3 March 1992, Ian Lang the then Secretary of State for Scotland said:

I am disappointed that both you and the Chancellor have reservations about publishing the booklet I have had prepared and printed setting out the details of the Government's expenditure and revenue in Scotland. I judge that it is just what is needed at present in our campaign to maintain the initiative and undermine the other parties. This initiative could score against all of them.

(as cited in Wilson, 1997)

In the end, this 'booklet' was published later on in 1992 and GERS landed on the political scene for the first time.

The creation and framing of an analytical document to suit the agenda of the government of the day - supported by a political interpretation (or spin) - was by no means new, and is still a practice used today. For example, in the run up to the 2014 referendum, both the Scottish

\footnotetext{
${ }^{7}$ They now do both - see ONS (2019) and HM Treasury (2020)
} 
and UK Governments published 'analytical' documents designed to strengthen the policy and political arguments of their Ministers. But the spin accompanying GERS from all sides in the political debate has, undoubtedly, 'damaged' the integrity of the publication (Heald and McLeod, 2002). The publication was used by the Scottish Office to build for themselves - in their eyes - a clear financial argument in favour of the Union, and to set out the costs of devolution or independence.

Publication drew an immediate response from opposition parties. Those in favour of devolution argued that the figures showed that Scotland benefited greatly from the UK but as Stevens (1995: 76) argued 'the existence of budget deficits and substantial transfers of funds from England to Scotland does not undermine the basic case for devolution'. Instead, they argued that the figures showed that a more nuanced form of fiscal devolution - including retaining the Barnett Formula - and modest tax devolution was desirable. Shifting the burden to Scottish taxpayers or to bring Scottish spending levels in line with England would be the 'politics of Disneyland' (Stevens op cit. pp. 77).

The figures were of course a challenge to the SNP and those advocating independence. Their response was largely to criticise GERS as a flawed technical statistical exercise and an inaccurate reflection of an independent Scotland (Scottish National Party, 1997). The SNP published their own 'alternative GERS' publications - for example Scotland Pays her Way in 1996; It's The Scots Who Pay in 1997 and Scotland's 21st Century Opportunity: Government Expenditure and Revenues in Scotland in 2001. They also argued that if the GERS methodologies were extended back over time, and crucially to the period when North Sea revenues were buoyant in the 1980s, Scotland would be in relative (and possible absolute) fiscal surplus (see the response from the Chief Secretary to the Treasury to a Parliamentary Question from Alex Salmond MP, 13 January 1997, UK Parliament 1997).

In an argument that still resonates today, many of the most thoughtful voices in the SNP argued instead that the GERS numbers were an irrelevance and said little about the future of an independent Scotland. On commenting on debates about Scotland's fiscal position back in 1997, the economist, future MSP and author of the SNP's Growth Commission report Andrew Wilson argued:

This discussion needs to get off the starting blocks and onto the more substantial issues about what sort of country Scotland must be to meet the economic challenges of the next century.

Wilson (1997)

In 2007, the Scottish Parliament's Finance Committee - led by Convenor Wendy Alexander and Deputy Convenor John Swinney - held an evidence session on GERS, including taking evidence from Scottish Government officials (Scottish Parliament, 2007). Perhaps anticipating the possibility of a SNP led government securing power, the 2007 GERS publication was cancelled with a full review taking place. The 2008 revised format was - in a complete about 
turn - warmly welcomed by the then SNP-led Scottish Government. As the political commentator lain Macwhirter argued, and picking up the Scottish football analogy, it was as though those using GERS to argue for or against constitutional change 'had swapped shirts' (Macwhirter, 2008). What caused this?

The reason for this apparent change in position was largely a matter of timing. Yes, the publication was largely praised for having been improved (Cuthbert \& Cuthbert 2008; McLaren at al. 2008), but high oil revenues happened to tip Scotland's relative fiscal position to be in a stronger position than for the UK as a whole (Scottish Government, 2008a).

John Swinney, then Cabinet Secretary for Finance and Sustainable Growth is quoted following publication as saying -

The GERS analysis shows Scotland in surplus on the current budget in both 2005-06 and 2006-07. With a current budget surplus in 2006-07 of over $£ 800$ million - in the context of a UK deficit of over $£ 4$ billion - the flow of resources from Scotland to the rest of the UK is some $f 1.2$ billion.

Scotland stands on a firm financial footing. And independence holds out the prospect of a flourishing and economically successful Scotland.

(Scottish Government 2008b)

Backed-up by ongoing large inflows of North Sea tax revenues - at least by recent standards the run-up to the 2014 independence referendum was marked by both the UK and Scottish Governments using GERS to back-up their arguments.

For the SNP and Yes Scotland, the narrative was now that GERS showed that Scotland was in a stronger position than the rest of the UK. The SNP-led Scottish Government also took the opportunity of being in government to proactively being to publish estimates of Scotland's long-term fiscal position (see for example, Scottish Government, 2013a). An internal memo released under Freedom of Information showed that using the GERS methodology and making a number of historic assumptions, Scotland would have run substantial surpluses in the early 1980s, which it was argued could have been invested. (Scottish Government, 2012).

For the UK Government and Better Together, GERS still showed that Scotland had higher public spending than the rest of the UK with this only backed up by - in their view unpredictable oil revenues. The UK Government used projections based upon GERS to claim that that Scots would be $£ 1,400$ per head worse off with independence compared to remaining within the Union (HM Treasury, 2014). In contrast, the Scottish Government's White Paper contained different forecasts that put Scotland in a stronger fiscal position than the UK on day one of independence (Scottish Government, 2013b). Scottish Ministers - from Alex Salmond to Nicola Sturgeon - spoke repeatedly of Scotland being 'in a fiscally stronger position than the rest of the UK' according to GERS (Scottish Government, 2013b).

GERS has also had an important influence on the wider devolved policy debate in Scotland. Just as in the mid-1990s when GERS swayed the opinion of policymakers to fund the new 
Scottish Parliament largely from the continuation of the block grant from Westminster as oppose to full tax devolution or tax assignment as the Scottish Constitutional Convention had initially suggested, the new-look GERS has underpinned the transfer of more powers to Holyrood. The GERS figures were pivotal in shaping both the Calman Commission recommendations and subsequent Scotland Act 2012 (UK Government 2012), and the Smith Commission recommendations and subsequent Scotland Act 2016 (UK Government 2016). The fiscal provisions in both Acts relied heavily on the estimated shares of revenues collected in Scotland, and crucially the reliability of such estimates, when deciding which taxes to devolve (Torrance, 2020).

Post 2014, and the collapse in the oil price, the GERS numbers have become much more politically challenging for independence supporters to interpret, particularly arguments that Scotland's fiscal position is stronger than the UK. Their response has been threefold.

First, some have chosen to return to criticism of the GERS report, citing its political origins, the methodological approach taken or the data used. Roy (2017) provides a rebuttal of these arguments. A roundtable session on Scottish economic statistics with senior economists for the Scottish Parliament's Economy Committee in 2017 (Scottish Parliament, 2017) reached a similar consensus. However, such views do still carry considerable traction on social media although the mainstream SNP and Scottish Government has distanced itself from such views ${ }^{8}$.

Second, others have pursued an argument that whilst Scotland would start from a challenging fiscal position, navigating through that would be possible with good governance and pro-growth policies. This was the approach taken by the SNP's Sustainable Growth Commission in 2016.

Third, and building on this, the argument for many has returned full circle to stress the importance that any weak GERS numbers reflect Scotland within the UK and thus show that Scotland is not fulfilling its full potential:

I do not dispute that Scotland's public finances, as estimated within the UK model, run a deficit that is higher than the best small countries we would seek to emulate, but the GERS assessment reflects a structural problem with the UK: it is one of the most unequal countries in the developed world.

Andrew Wilson, Chair Sustainable Growth Commission (Wilson 2020).

With COVID-19, the fiscal position of both Scotland and the UK will deteriorate markedly in the near future. Whether this will change people's minds is open to debate (Roy and Eiser, 2020).

\footnotetext{
${ }^{8}$ For example, the SNP's Sustainable Growth Commission of 2016 stated that 'for all its conceptual and practical limitations we see very little value in comprehensively challenging the detail of the GERS report' (page 237, Sustainable Growth Commission 2016).
} 


\section{Limitations of GERS}

As highlighted, the GERS report has been controversial. Primarily, because of the political context in which it is debated. But there have also been wider criticisms beyond political and constitutional questions that are worth reflecting upon. Some of these criticisms are fair, some less so.

For example, some believe GERS to offer a definitive insight on the health of the Scottish economy. But this is wrong. GERS only - and quite deliberately - focusses upon public finances. It does not, for example, cover issues around the growth performance of the Scottish economy, its economic resilience or wider issues around the broader financial performance of Scotland, such as the transfer of private financial resources between Scotland and the rest of the UK or the public sector asset and liability base in Scotland. In recent years, the Scottish Government has undertaken useful analysis to extend the coverage of economic statistics in Scotland with the aim of providing a much fuller picture of the health of the Scottish economy. This includes for example, publication of Gross National Income figures for Scotland (Scottish Government 2019). These show a net outflow of income out of Scotland.

In recent times, there have also been criticisms about GERS as it relies upon estimates. But as economists at the Fraser of Allander (2020) have argued, estimates are nothing new in economic statistics. Most of the information that we have on the Scottish economy - good and bad - are in the form of estimates, including GDP, unemployment, exports and earnings. What matters is whether or not these estimates are accurate. As Margaret Cuthbert pointed out in evidence to the Scottish Parliament in 2017, 'An estimate is worthwhile if it has a small deviation on either side and I would say that tremendous work has been done to try to reduce the uncertainty over some of these statistics.' (Scottish Parliament 2017).

To help address this, in recent years there has been more user consultation with respect to the methods used ${ }^{9}$. The Scottish Government also helpfully now publish confidence intervals around some key elements of estimation. These provide useful context. For example, in the most recent GERS a 5\% confidence interval for VAT is +/- $£ 242 \mathrm{~m}$; in the context of total revenue of $£ 11,015 \mathrm{~m}$ (equivalent to $2.2 \%$ ). That is not to say that GERS is not subject to criticism. Early on the methods used - for example, when estimating different tax revenues were relatively crude and subject to a wide margin of error (Gibson, 2007). Three major reforms have taken place since then, including a full review in 2007 and 2008.

Firstly, there is now much more openness and transparency about the methodologies used. The new revised publication stretched to 99 pages, compared to 21 pages in the 1992 GERS.

\footnotetext{
${ }^{9}$ See https://www.gov.scot/publications/about-government-expenditure-and-revenue-scotland/pages/faqs/
} 
Secondly, North Sea Oil revenues are now no longer treated as an afterthought. In early publications, these revenues were added in as part of 'sensitivity' analysis using ad hoc percentage illustrative shares of Scottish North Sea oil and gas reserves (e.g. 90\%, 80\%) rather than treated as a key source of actual Scottish revenue. Alex Kemp and Linda Stephen from the University of Aberdeen were commissioned to provide be-spoke estimates of Scotland's geographical share of North Sea revenues (Kemp and Stephen 2008). From 2008 onwards, oil and gas revenues were included - both on a per capita basis and a geographical basis - as a core revenue in GERS ${ }^{10}$. Thirdly, and most significantly, much of the underlying data underpinning the GERS report, and in particular detailed spending by government departments, has been reviewed, improved and made publicly available.

Much of this stems from the work of Jim and Margaret Cuthbert, two of Scotland's finest analysts of the last 50 years, who over a years exposed a series of flaws and errors in the GERS methodology for allocating expenditure to Scotland (Cuthbert \& Cuthbert 1998; Cuthbert \& Cuthbert 2002 and Cuthbert \& Cuthbert 2005). Met initially by a wall of silence from HM Treasury, the passing of the UK's Freedom of Information Act in 2000 provided an opportunity for the Cuthberts to unlock the underlying databases that HM Treasury used to apportion public expenditure to different parts of the UK. Prior to this HM Treasury had taken 'a proprietary view of its public expenditure database and denies access to this even to the pre-devolution territorial departments and the post-devolution Executives' (Heald, 2001).

The Cuthberts' analysis found a range of errors, amounting to billions of pounds at the UK level and hundreds of millions of pounds at the Scottish level. Errors were in both directions, but in the main the findings pointed to GERS over-allocating significant amounts of public expenditure for Scotland each year. For example, they found numerous instances where expenditure on functions like prisons, court services and nature conservation had been assigned as 'non-identifiable' in England, but expenditure on the same services in Scotland was 'identifiable'. The result being that Scotland was allocated a per capita share of English spending in the GERS accounts as well as $100 \%$ of its own spending in these areas. In total, over $£ 4$ billion of such mis-allocation was identified for the UK as a whole, equivalent to over $£ 500$ million for Scotland. Other errors included misallocation of spending by function, so comparisons between different parts of the UK on relative spending priorities were inaccurate. The impact of the work of Jim and Margaret Cuthbert still resonates today. It helped to usher in a fundamental review of the entire GERS methodology to make it more fitfor-purpose.

A final legitimate challenge of GERS is that it frames Scotland relative to the UK as a whole. In reality, the rest of the UK is far from homogenous. It is well documented that the UK is an unbalanced economy on a regional basis, reflecting in part London's position as a global hub for economic and financial activity. Policymakers have for years discussed various ways of

\footnotetext{
10 The geographical split used is that for fisheries demarcation purposes for devolved fisheries policies.
} 
shifting this balance, including George Osborne's ambition for a 'Northern Powerhouse' and the current UK Government's 'levelling-up' agenda (McCann, 2019). By comparing Scotland to the rest of the UK, these differences are not picked up. Over time, the GERS approach has been adopted in Northern Ireland and Wales (see for example, Ifan et al. 2019). New data, building upon the GERS framework, by the Office for National Statistics was published for the first time in 2017, showing revenue and expenditure for the NUTS 1 areas of the UK, which includes Scotland, Northern Ireland, Wales, and the nine regions of England.

This showed that in 2019, only three regions (London, South East and East of England) were estimated to have raised more in revenue than was spent for theses localities. Nine other regions and devolved nations were in relative deficit (ONS, 2019). In essence, what this analysis shows is that far from Scotland being the 'exception' in the UK, it is London and the South East that are the 'exception' with so much economic activity in the UK skewed to that part of the country.

Interestingly, and despite this, GERS still only publishes comparisons with the UK as a whole. This arguably is a weakness in the publication as it skews the debate here in Scotland to be largely focussed upon comparing Scotland to the UK as a whole, when that UK figure is heavily influenced by just two regions.

\section{What GERS tells us and does not tell us}

GERS tells us a number of interesting things about the Scottish economy. The most recent GERS was published in August 2020 and this is our focus. Firstly, public spending per head in Scotland is significantly higher than the UK average. Looking at identifiable head for example, across the UK we see a spending advantage for Scotland in the range of 15\% to 20\% (see Table 1).

\section{[Table 1 around here]}

Note this relative advantage is driven by identifiable expenditure differences and not by any apportionment method for non-identifiable expenditure. In short, it is expenditure both 'in' and 'for' Scotland. There are two reasons for this: higher devolved spending as a result of the Barnett Formula and greater take-up of some key social security payments. The nature of the funding settlement for devolved expenditure - since before the Barnett Formula (Cuthbert, 2020) - has locked in higher relative public spending on all manner of public services, from health through to education, into the Scottish Budget. Many authors have described the perceived slow degree of convergence between UK and Scottish per capita expenditure levels (McCrone 1999; Cuthbert 2001 and Cuthbert 2020)

On social security - particularly those tied to ill health - average spending in Scotland is higher than in the rest of the UK on a per capita basis (8.3\%) (see Table2). 


\section{[Table 2 around here]}

ONS data shows that in comparison to most English regions, Scotland does have relatively high levels of spending on social security, although Scotland does spend less per head than Wales and Northern Ireland (see Figure 1).

\section{[Figure 1 around here]}

Secondly, of the relative growth in public expenditure for Scotland, health spending has risen the most over the period. As Figure 2 shows, outside of social security, health is the largest element within total public sector spend.

\section{[Figure 2 around here]}

As the Figure 3 highlights, most parts of the public sector saw rising spending during the first decade of devolution. But since 2010 onwards, growth has been more muted. The exception to this is health, which has continued to rise on a near linear basis year on year.

[Figure 3 around here]

Thirdly, and turning to taxation, it is estimated that, on a per capita basis, Scotland raises slightly less than the UK average in terms of public sector revenues. In all years between 1999 and 2014, Scotland raised slightly higher than the UK as a whole on a per capita basis when North Sea revenues were included. But since the downturn in the oil and gas industry from 2014 , with the fall in oil prices and a more generous fiscal regime, average per capita revenues raised in Scotland are slightly lower than the UK equivalent (see Figure 4).

[Figure 4 around here]

Again, this is not that surprising when looking at the wider performance of the Scottish economy. Overall, economic activity in Scotland is not too dissimilar from the UK average (albeit slightly lower). For example, Gross Value Added on a per capita basis was $96 \%$ of the equivalent figure for the UK in 2019. Gross Disposable Household Income is $93 \%$ of the UK level in 2018. This gap between Scotland and the UK on per capita income can be explained, in part, by the fact that there are fewer people in Scotland at the top of the income distribution where taxes are raised, alongside the significantly higher amounts of corporate and wealth taxes raised in the City of London.

Once again therefore, comparisons with the different parts of the UK are important (see Figure 5). Scotland is closer to the UK 'average' than many of the other devolved nations and English regions. Only four areas - London, South East, England, and East of England - were estimated to raise more revenue per person than Scotland in 2018/19 according to the latest data (ONS, 2019).

\section{[Figure 5 around here]}


Fourthly, Scotland's tax base, like the UK as a whole is concentrated in a relatively small number of taxes. Figure 6 shows the composition of onshore revenues in 2019/20. Over 60\% of total revenues estimated to have been raised in Scotland come from just three sources, income tax, national insurance and VAT. Two of these are primarily taxes on employment. This is a narrow tax base to draw upon.

\section{[Figure 6 around here]}

Fifthly, GERS highlights the tax and spend lines which are devolved to the Scottish Parliament and the changes over time (see Figure 7). The most significant tax powers since devolution coming through in Scotland Act 2016, when Holyrood was given power of income tax rates and bands (for NSND Income).

\section{[Figure 7 around here]}

Finally, Scotland's estimated net fiscal position - and its relative position vis-à-vis the UK - is closely correlated with North Sea revenues. When North Sea revenues have been high, even with higher public expenditure, Scotland's fiscal position has been close to - if not better than - that for the UK as a whole. When North Sea revenues have fallen back, as in recent years, Scotland's relative fiscal position vis-à-vis the UK has also slipped back (see Figure 8).

\section{[Figure 8 around here]}

The fall in North Sea revenues can clearly be seen in Figure 9 which tracks the differential between onshore and total revenues since 2008.

\section{[Figure 9 around here]}

The fall in North Sea tax receipts can be explained by both lower oil prices and production, cuts in tax rates to help support the sector, and as fields are being decommissioned, producers are able to offset the costs of cleaning up old installations against current tax liabilities.

Again, Scotland is not unique in having an estimated weaker net fiscal position vis-à-vis the UK as a whole. According to the comparable GERS exercise now undertaken by ONS, all but three of the 12 UK countries and regions had a fiscal deficit in 2018-19 (see Table 3).

\section{[Table 3 around here]}

\section{What does GERS tell us about an independent Scotland?}

As highlighted, GERS has been central to debates on Scotland's constitutional future. It was key in 2014, being used extensively by both sides. So, with the prospects of a second independence referendum increasing, what can it legitimately say about an independent Scotland? 
On the one hand, GERS reflects the position under the current constitutional settlement. It is a backward-looking estimate of spending and revenues in previous financial years. This means that if an independent Scotland were to bring about structural changes to the economy and society, the figures in GERS say little about the long-term finances of an independent Scotland. As Bell and Dow wrote in this journal in 1995, 'it is unreasonable to assume that economic behaviour, and thus revenues and expenditures, would be the same after constitutional change as before' (Bell and Dow 1995). Indeed, it follows that if the very purpose of independence is to take different choices, then this will lead to different fiscal outcomes.

Similarly, the possible financial costs and risks, or savings and opportunities, of implementing a new constitutional framework are not considered in GERS. It also does not report the effects of faster or slower growth in an independent Scotland. An independent Scotland would also be subject to new macroeconomic risks and opportunities that would have to be managed. As Roy and Eiser (2020) argue, these risks have arguably become tougher in many ways since 2014. The collapse in the oil prices, Brexit and the COVID-19 recession have all weakened both the Scottish and UK fiscal outlook (McLaren 2019). Estimates produced of the possible fiscal position faced by the UK for 2020-21 suggest it could be as high as $19-20 \%$ (OBR, 2020). This means it is likely that the GERS estimates for 2020-21 could be high still (Phillips, 2020).

By presenting a picture of where Scotland is today GERS provides a valuable focus for the starting point of a discussion about the transition to independence. With Scotland spending significantly above the UK average on a per capita basis, and raising revenues that are broadly in line with the UK average, Scotland has a gap between the two sides of its balance sheet, under the current constitutional settlement. This conclusion is identical to that reached by the then Chief Economist of the Scottish Government Andrew Goudie in this journal in 2002 (Goudie 2002).

Between 1998 and 2014 oil revenues could have been relied upon to make up this difference at least in the short-run. But this is no longer the case and unlikely to be so in the future. Starting life with a fiscal deficit in the low teens or high single digits would be a challenge. It would test the credibility of markets and investor confidence. It could have political implications too, ranging from questions over commitments to be more generous on key public services through to the ability to meet the acquis for EU membership and the type of currency chosen. As acknowledged in the SNP's Sustainable Growth Commission report, there will need to be a plan to bring down the deficit over time. A mix of spending restraint, higher taxes and faster growth are likely to be needed.

Of course, Scotland could make immediate savings by spending less on current UK-wide priorities - e.g. defence and foreign aid. But these are not likely to have a material impact upon the numbers. For example, removing Defence from the figure for Scotland would only 
reduce the 2019/20 deficit by 2 percentage points. Similarly, not taking on any UK debt would reduce the deficit only to $6.0 \%$ using the 2019/20 figures. Other changes would be required. This is not to say that Scotland could never run a balanced fiscal position or that that any fiscal pain in the short-run might not be economically worth it in the long-run. But it does highlight the tough choices that would face an independent Scotland from day one. Just like the UK, there are also important issues to consider, particularly with regard to the longrun sustainability of the public finances with an ageing population. GERS provides useful information on the starting point for meeting that.

So far, we have seen limited evidence that those in favour of independence are in a position to put forward a detailed fiscal prospectus just yet - particularly beyond the Sustainable Growth Commission's pre-COVID view. The narrative has now settled upon a line of argument that 'We cannot influence the starting point we inherit', we have no option other than to 'start from here, but we have choices to make' (Wilson 2020). What these choices are remains a question unanswered (McLaren, 2020).

\section{Conclusion}

In this paper we have traced the evolution of the GERS report over time. After starting out life as a political exercise, GERS has evolved to become the go-to report on Scotland's public finances. For all its controversy, it is now accepted within the academic and public policy community as a useful source of information. Outside of Scotland, GERS has transformed our understanding of regional public finances across the UK. The efforts of Jim and Margaret Cuthbert to unlock the spending lines used in GERS ultimately led to establishment of the annual publication of the Country and Regional Analysis (CRA) database. This is now used as the basis for discussions about public spending across the UK, helping to inform fiscal debates for the devolved nations and English Regions.

But GERS has also always been pivotal to the constitutional debate in Scotland, and even more so in the run to 2014 and beyond. No one can tell what might happen next on Scotland's future constitutional journey. But debates on greater autonomy for the Scottish Parliament continue to gather momentum, not least as a result of Brexit and the outcome of the 2021 Scottish election. At the same time, questions around possible replacement options for EU Structural Funds will no doubt open up debates about 'fairness' of funding across the UK. Scotland's relative spending advantage may come under scrutiny, perhaps as part of the 2021 review of the Scottish Fiscal Framework. A 'needs assessment' exercise across the UK could take on many forms, but it is unlikely to yield a result in Scotland's favour.

On the question of independence, supporters are entirely correct to point out that focussing upon a backward-looking static exercise misses the point that the purpose of constitutional change is to ensure that the future is not like the past. But by setting this starting point, 
opponents are right to point out too that this gives an indication of the scale of challenge that an independent Scotland would face in attempting to deliver the same volume and level of public spending than it currently does at the moment. It is impossible to go much further on the assessment that can be made beyond this, given the high level of uncertainty that exists over the costs of transition and big macroeconomic issues, such as the choice of currency or membership of the European Union.

If there is to be a second independence referendum, hopefully the debate over Scotland's fiscal future will be informed by evidence and fact. After a rocky start, GERS should be able to provide an informed basis for such a debate from all sides and greatly help the general public to make an informed choice whatever outcome wins in the end.

\section{References}

Bell, D. \& Dow, S. (1995), Economic Policy Options for a Scottish Parliament, Scottish Affairs, 13, Autumn, pp. $42-67$.

Brown, A. (2000), Designing the Scottish Parliament, Parliamentary Affairs, 53(3), pp. 542 556 https://doi.org/10.1093/pa/53.3.542

Butler, D., and Kavanagh, D. (1992), The British General Election of 1992, Palgrave Macmillan, DOI 10.1057/9780230372092

Cuthbert, J.R. (2001), 'The effect of relative population growth on the Barnett squeeze', Fraser of Allander Quarterly Economic Commentary, 26(2), pp. 34- 37.

Cuthbert, J.R. (2020), 'Ambiguous no more: Time to de-mystify the Barnett Formula', Scottish Affairs, 29(3), pp. $431-449$.

Cuthbert, J.R. and Cuthbert, M. (1998), 'A Critique of GERS: Government Expenditure and Revenue in Scotland', Fraser of Allander Institute Quarterly Economic Commentary, 24(1), pp. 49-58

Cuthbert, J.R. and Cuthbert, M. (2002), 'The Treasury Funding Statements as a tool in monitoring the devolution settlement', Fraser of Allander Institute Quarterly Economic Commentary, 27(4), pp. $67-78$

Cuthbert, J.R. and Cuthbert, M. (2005), 'A Constructive Critique of the Treasury's Country and Regional Analysis of Public Expenditure', Fraser of Allander Institute Quarterly Economic Commentary, 30(3), pp. $47-55$.

Cuthbert, J.R. and Cuthbert, M. (2008), 'Opening up the books on the true state of Scottish finances', Sunday Herald, 22nd June, 2008.

Fraser of Allander (2020), A Guide to the Government Expenditure and Revenue Scotland (GERS) Report, https://fraserofallander.org/gers-guide/ 
Gibson, H. (2007), 'Evidence to the Scottish Finance Committee on GERS', Scottish Parliament Finance Committee Briefing Paper, FI/S2/07/01/1, Scottish Parliament, Edinburgh https://archive.parliament.scot/business/committees/finance/papers-07/fip07-01.pdf Goudie, A. (2002), 'GERS and Fiscal Autonomy', Scottish Affairs, 41(1), pp. $56-85$. Heald, D. (2001), 'Financing Devolution in Practice', Aberdeen Papers in Accountancy, Finance \& Management, University of Aberdeen, http://www.davidheald.com/publications/01dah1.pdf Heald, D., and McLeod, A. (2002), 'Fiscal Autonomy under Devolution: Introduction to Symposium', Scottish Affairs, 41(1), pp. $5-25$.

HM Treasury (2014), Scotland analysis: Fiscal policy and sustainability, HM Treasury, London, https://assets.publishing.service.gov.uk/government/uploads/system/uploads/attachment data/file/ 314359/Scotland analysis Fiscal policy and sustainability.pdf

HM Treasury (2020), Public Expenditure Statistical Analyses (PESA) 2020, HM Treasury, London, https://www.gov.uk/government/statistics/public-expenditure-statistical-analyses$\underline{2020}$

Ifan, G., Sion, C, and Poole, G. (2019), Government Expenditure and Revenue Wales 2019, Wales Fiscal Analysis, University of Cardiff, https://www.cardiff.ac.uk/ data/assets/pdf file/0004/1540498/Government-Expenditureand-Revenue-Wales-2019.pdf

Phillips, D. (2020), 'Scotland's implicit budget deficit could be around 26-28\% of GDP in 202021', IFS Observation, https://www.ifs.org.uk/publications/14982

Kemp, A., and Stephen, L. (2008), The Hypothetical Scottish Shares of Revenues and Expenditures from the UK Continental Shelf 2000 - 2013, University of Aberdeen, https://webarchive.nrscotland.gov.uk/20170410013228/http://www.gov.scot/Topics/Econo my/17858/ScotShareNorthSeaRevenue

Macwhirter, I. (2008), 'How Gers swapped shirts', Public Finance Magazine, July 3rd, https://www.publicfinance.co.uk/2008/07/how-gers-swapped-shirts-iain-macwhirter McCann, P. (2019), 'Perceptions of regional inequality and the geography of discontent: insights from the UK', Regional Studies, 54(2), pp. 256-267, https://doi.org/10.1080/00343404.2019.1619928

McCrone, G. (1999), 'Scotland's Public Finances from Goschen to Bamett', Fraser of Allander Quarterly Economic Commentary, 24(2), pp. 30-46.

McLaren, J. (2019), Analysis of 'Government Expenditure and Revenue Scotland (GERS) 2019', including implications for a Second Independence Referendum, http://scottishtrends.co.uk/wp-content/uploads/2019/08/GERS-2019-Aug-24819.pdf 
McLaren, J. (2020), GERS, COVID and Scottish Independence (revisiting economic and fiscal arguments around a Second Independence Referendum), http://scottishtrends.co.uk/wpcontent/uploads/2020/08/GERS-COVID-and-independence-.pdf

Mclaren, J., Harris, R., Armstrong, J., and Moffat, J. (2008), Analysis of Government

Expenditure and Revenues Scotland (GERS), 2006-07 Publication, Centre for Public Policy

Research, University of Glasgow https://www.gla.ac.uk/media/Media 84533 smxx.pdf

Mitchell, J. (2009), Devolution in the UK, Manchester University Press,

https://www.jstor.org/stable/j.ctt155j9bx

OBR (2020), Economic and fiscal outlook - March 2020, London,

https://obr.uk/efo/economic-and-fiscal-outlook-march-2020/

ONS (2019), Country and regional public sector finances: financial year ending 2019, Office for National Statistics,

https://www.ons.gov.uk/economy/governmentpublicsectorandtaxes/publicsectorfinance/articles/cou ntryandregionalpublicsectorfinances/financialyearending2019

Roy, G. (date?), Estimating Scotland's Fiscal Position, https://fraserofallander.org/scottisheconomy/estimating-scotlands-fiscal-position/

Rey, and Eiser, D. (2020), Public Revenues and Spending, in Scotland's new choice Independence after Brexit, Editors Eve Hepburn, Michael Keating and Nicola McEwen, Chapter 6, Centre for Constitutional Change, University of Edinburgh.

Scottish Government (2008a), Government Expenditure Revenue Scotland 2007/08, Scottish Government, Edinburgh,

https://webarchive.nrscotland.gov.uk/20170404031027/http://www.gov.scot/Publications/2008/06/ $\underline{18170334 / 0}$

Scottish Government (2008) Ministerial Press Release on GERS 2007/08, Scottish Government, Edinburgh

Scottish Government (2012), An Oil Fund for Scotland, paper released under Freedom of Information request in October 2013, https://www2.gov.scot/Resource/0043/00435599.pdf Scottish Government (2013a), Scotland's Economy: the case for independence, Scottish Government, May 2013, Edinburgh, https://www2.gov.scot/resource/0042/00422987.pdf Scottish Government(2013b), Scotland's Future, Scottish Government, Edinburgh, https://www.gov.scot/publications/scotlands-future/

Scottish Government (2019), Scottish national accounts programme: primary income account and gross national income for Scotland, Scottish Government, December 2019, Edinburgh, https://www.gov.scot/publications/scottish-national-accounts-programme-primary-incomeaccount-and-gross-national-income-for-scotland/ 
Scottish Government (2020), Government Expenditure Revenue Scotland 2019/21, Scottish Government, Edinburgh, https://www.gov.scot/publications/government-expenditurerevenue-scotland-gers-2019-20/

Scottish National Party (1997), The SNP General Election Budget 1997, Edinburgh, SNP

Scottish National Party (1996), Scotland Pays her Way, Edinburgh, SNP

Scottish National Party (1997), It's The Scots Who Pay, Edinburgh, SNP

Scottish National Party (2001), Scotland's 21st Century Opportunity: Government Expenditure and Revenues in Scotland in 2001, Edinburgh, SNP

Scottish Office (1992), Government Expenditure and Revenues in Scotland 1990-91, Scottish Office, Edinburgh,

https://webarchive.nrscotland.gov.uk/20170404031154/http://www.gov.scot/Topics/Statisti cs/Browse/Economy/GERS/GERS199091

Scottish Parliament (2007), 'Government Expenditure and Revenue in Scotland', Finance Committee Official Report 16 January 2007, https://archive.parliament.scot/business/committees/finance/or-07/fi07-0102.htm

Scottish Parliament (2017), 'Inquiry into Economic Data', Economy, Jobs and Fair Work Committee Official Report 19 September 2017, http://www.parliament.scot/parliamentarybusiness/report.aspx? r=11103

Stevens, J. (1995), 'The Scottish public finances in 1992/93', Fraser of Allander Quarterly Economic Commentary, 20(3), pp. 74 - 80. https://strathprints.strath.ac.uk/51634/

Sustainable Growth Commission (2018), Part B: The Framework \& Strategy for the Sustainable Public Finances of an Independent Scotland, Edinburgh, https://www.sustainablegrowthcommission.scot/report

Torrance, D. (2020), 'The settled will? Devolution in Scotland, 1998-2020', House of Commons Library Briefing Paper, Number CBP-8441, 6 April, http://researchbriefings.files.parliament.uk/documents/CBP-8441/CBP-8441.pdf

UK Government (2012), Scotland Act 2012, https://www.legislation.gov.uk/ukpga/2012/11/contents/enacted

UK Government (2016), Scotland Act 2016, https://www.legislation.gov.uk/ukpga/2016/11/contents/enacted UK Parliament (1997), Hansard 13 January 1997, HMT Ref 2- 0307, https://api.parliament.uk/historic-hansard/written-answers/1997/jan/13/revenue-andexpenditure-balance-scotland 
Wilson, A. (1997), 'Stuck on the starting blocks: a response to Mr Steven's comment on the SNP General Election Budget 1997', Fraser of Allander Quarterly Economic Commentary, 22(3), pp. 57-67. ISSN 0306-7866

Wilson, A. (2020), 'Scotland's public spending deficit makes case for independence', The Times, Saturday August 29, https://www.thetimes.co.uk/article/scotland-s-public-spendingdeficit-makes-independence-case-2ssffh9dl 
Table 1: Expenditure and Revenue per head: Scotland and UK: 2019/20 (f)

\begin{tabular}{|l|c|c|}
\hline & Expenditure & Revenue \\
\hline Scotland & 14,829 & 12,058 \\
\hline UK & 13,196 & 12,367 \\
\hline Difference & 1,633 & -308 \\
\hline
\end{tabular}

Table 2: Social protection spending: Scotland as \% of UK: $2019 / 20$ (f)

\begin{tabular}{|r|r|r|r|r|}
\hline $2015-16$ & $2016-17$ & $2017-18$ & $2018-19$ & $2019-20$ \\
\hline $8.8 \%$ & $8.7 \%$ & $8.7 \%$ & $8.8 \%$ & $8.8 \%$ \\
\hline
\end{tabular}

Source: GERS 2019-20

Figure 1: Social protection per head across the UK: 2019/20

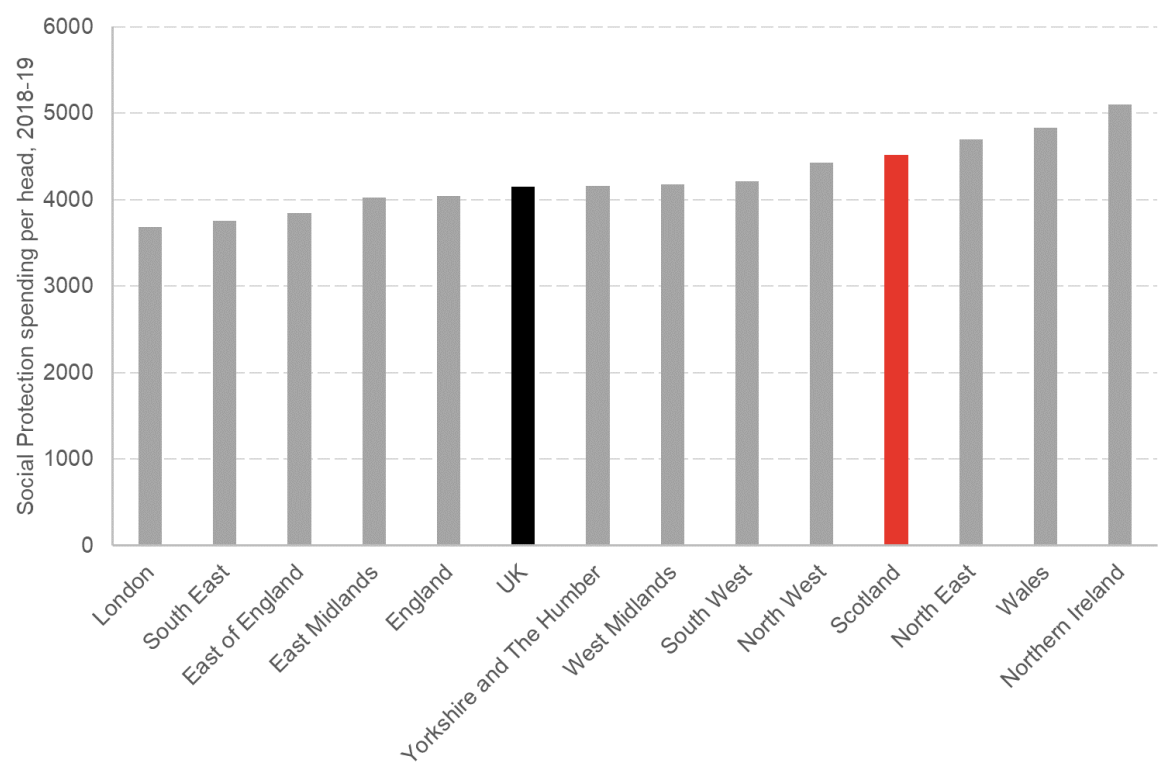

Source: ONS, Country and Regional Public Sector Finances, 2019-20 
Figure 2: Share of total public expenditure by function: 2019/20

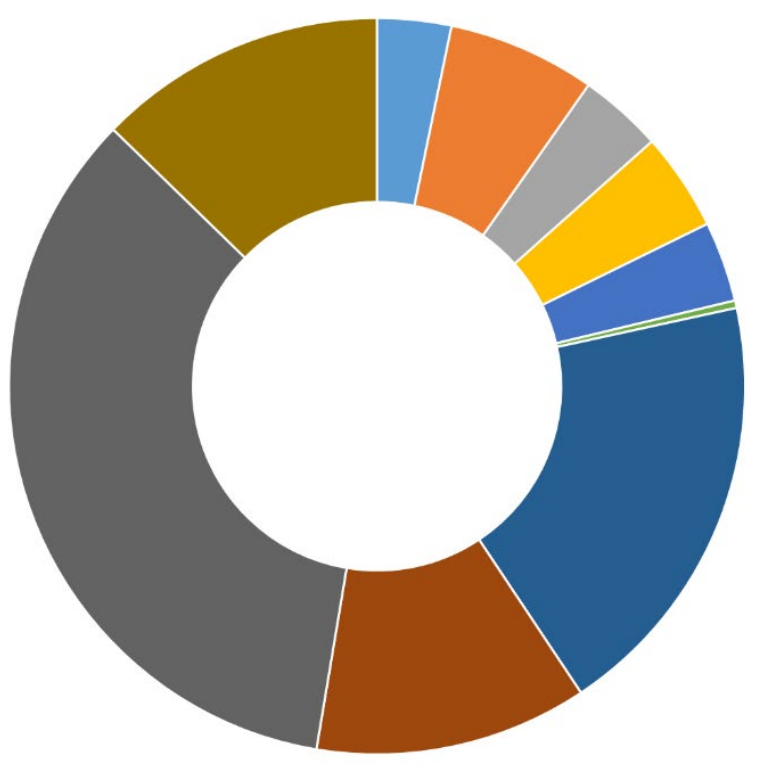

- General public services

- Public sector debt interest

- Defence

- Public order and safety

- Economic affairs (excl transport)

- Housing and community

amenities

Health

- Education and training

- Social protection

- Other

Figure 3: Total public current expenditure by function: 1998/99 - 2019/2011

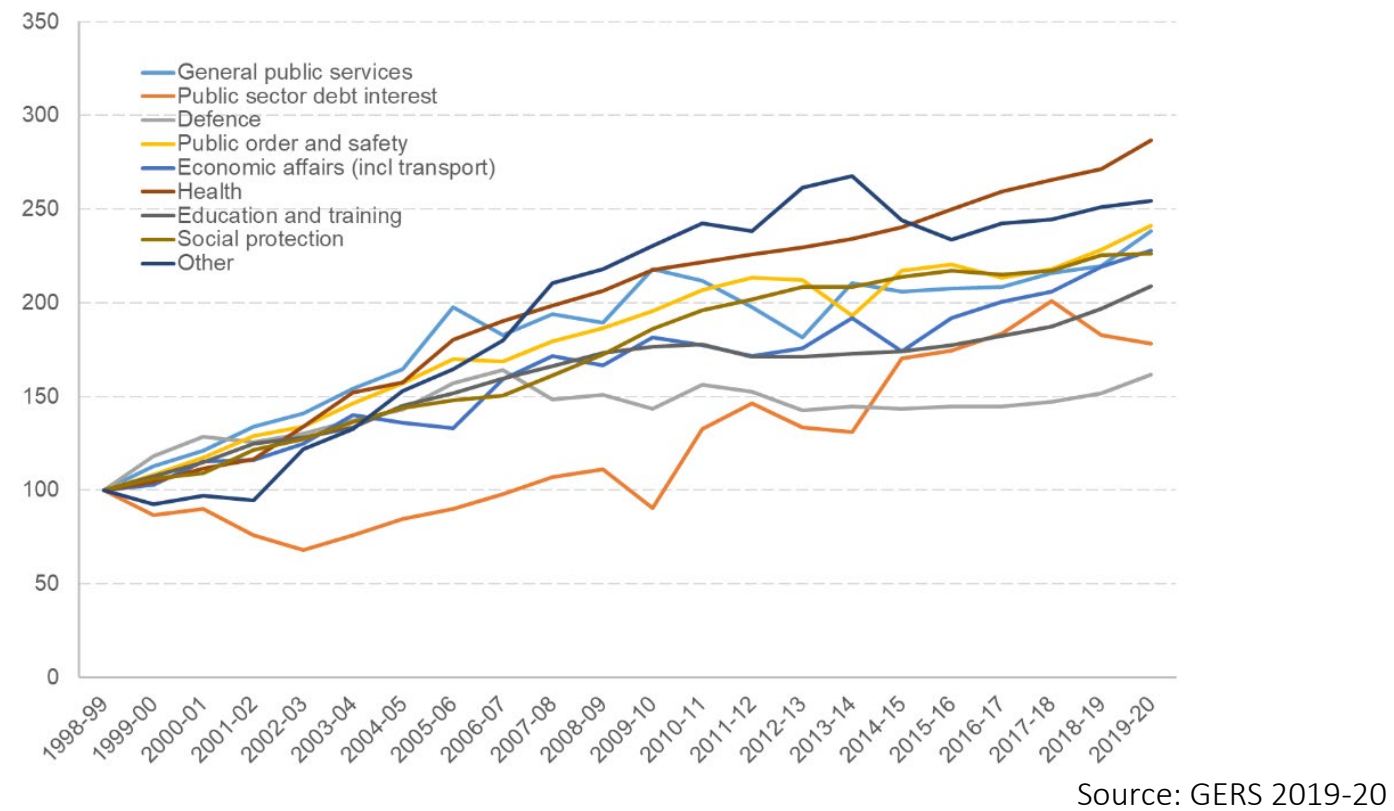

${ }^{11}$ Housing has been excluded from this figure due to the creation of the Housing Revenue Account in 2004/05, which skews interpretation. 
Figure 4: Public sector revenue per person in Scotland and the UK since 2010/11

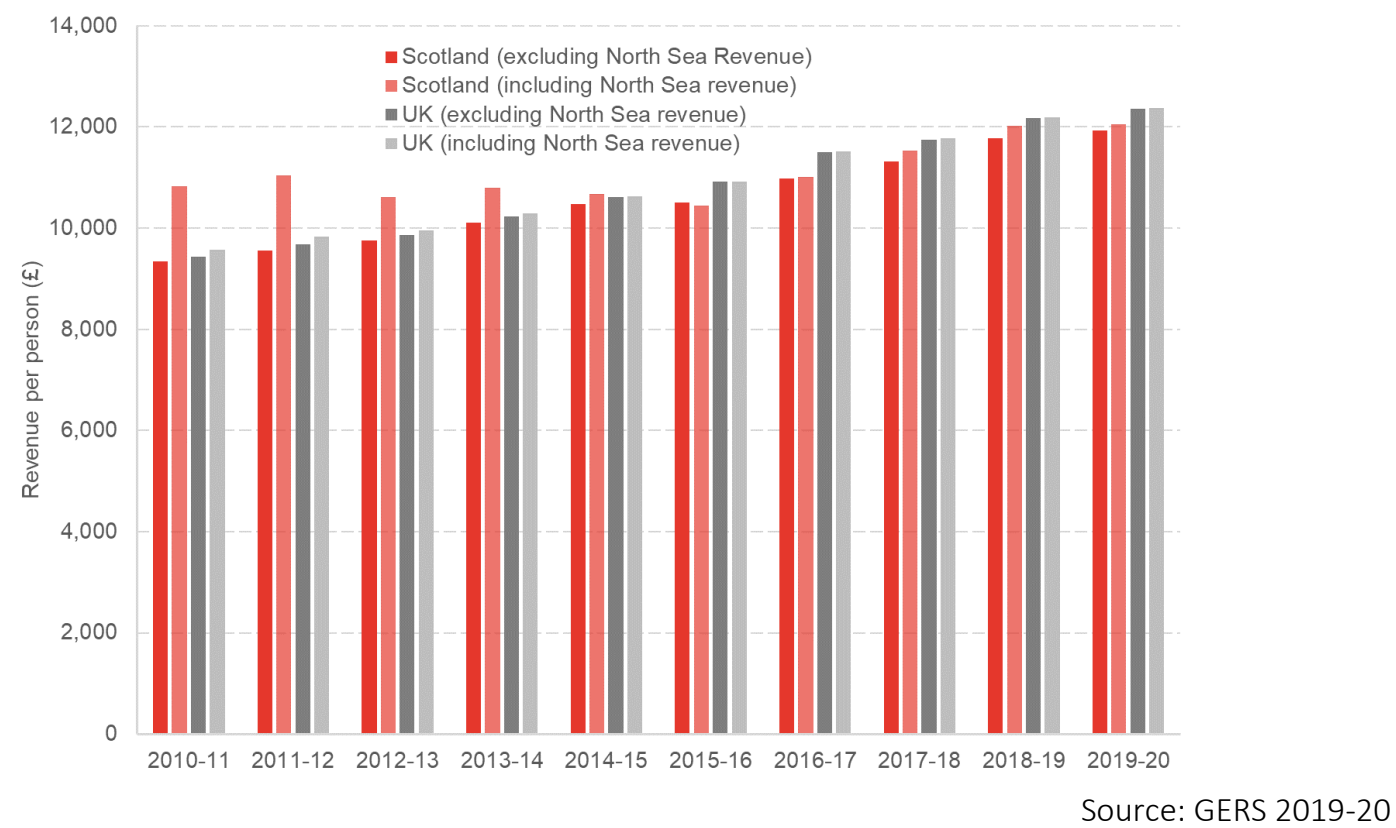

Figure 5: Country and regional revenue per person 2018/19

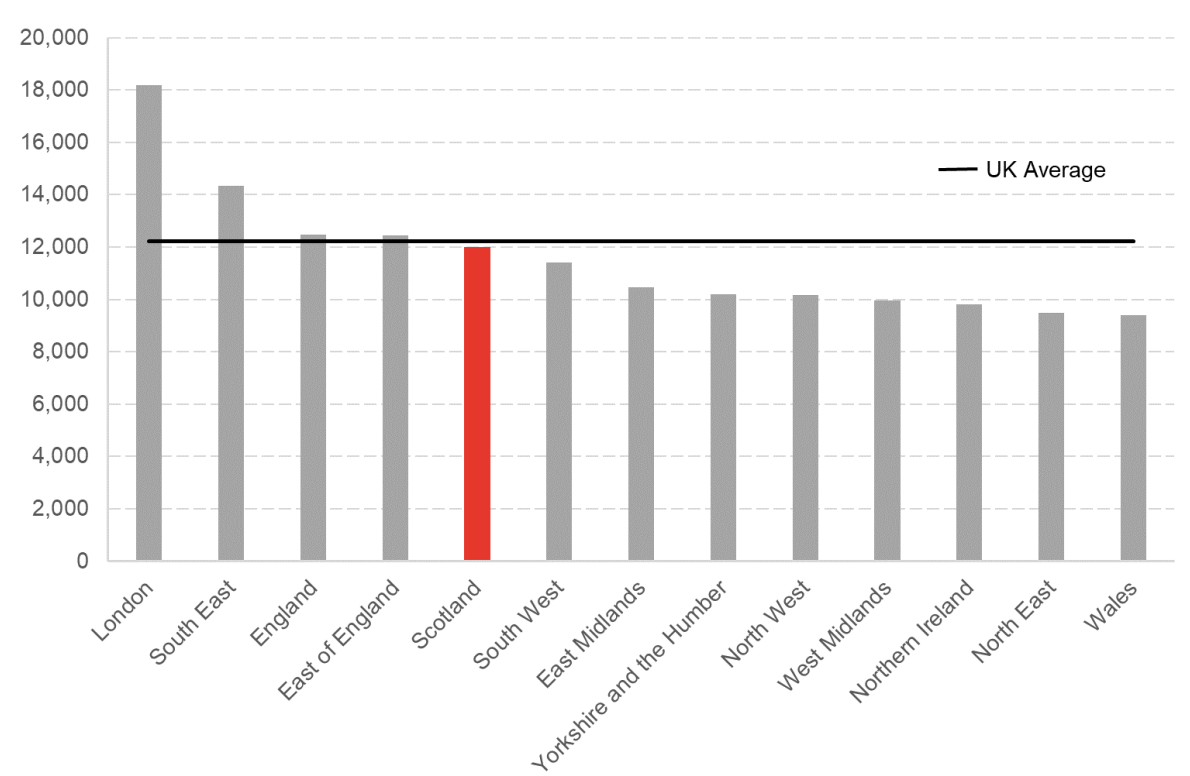

Source: ONS (2019) 
Figure 6: Composition of Scottish non-North Sea tax revenue 2019-20

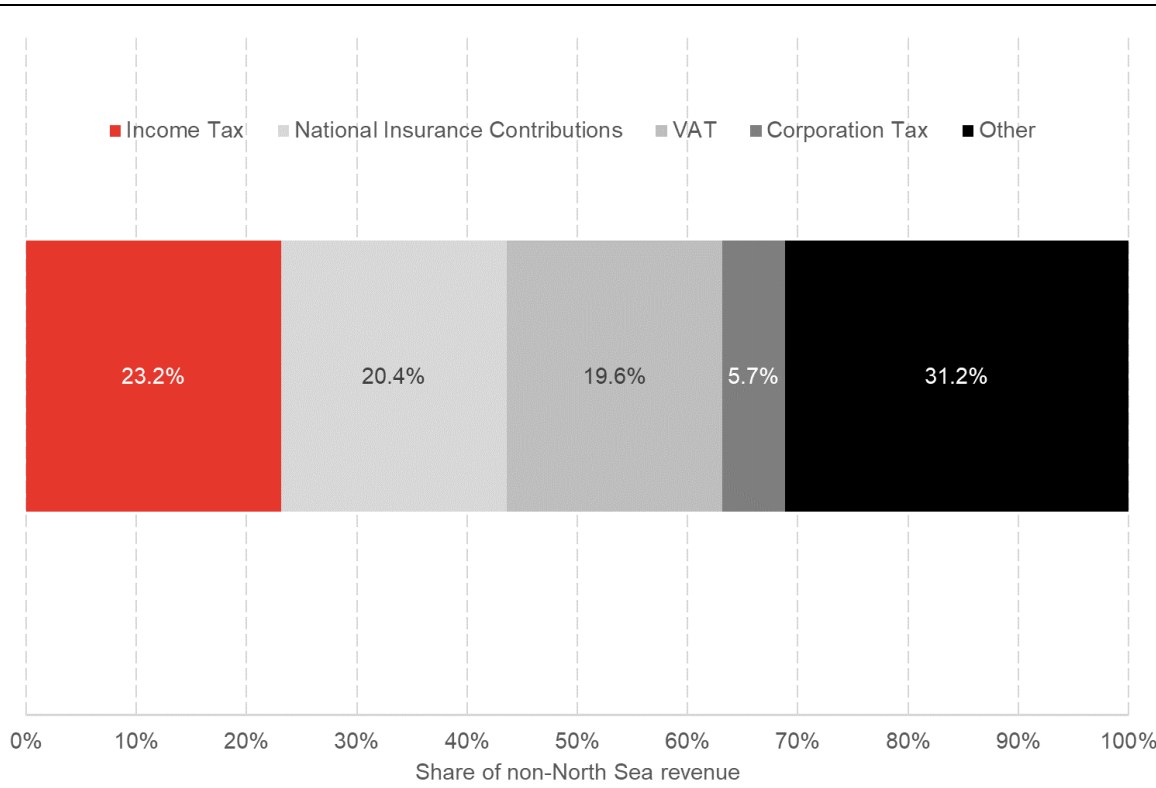

Source: GERS 2019-20

Figure 7: Devolved and Reserved Revenue 2019-20

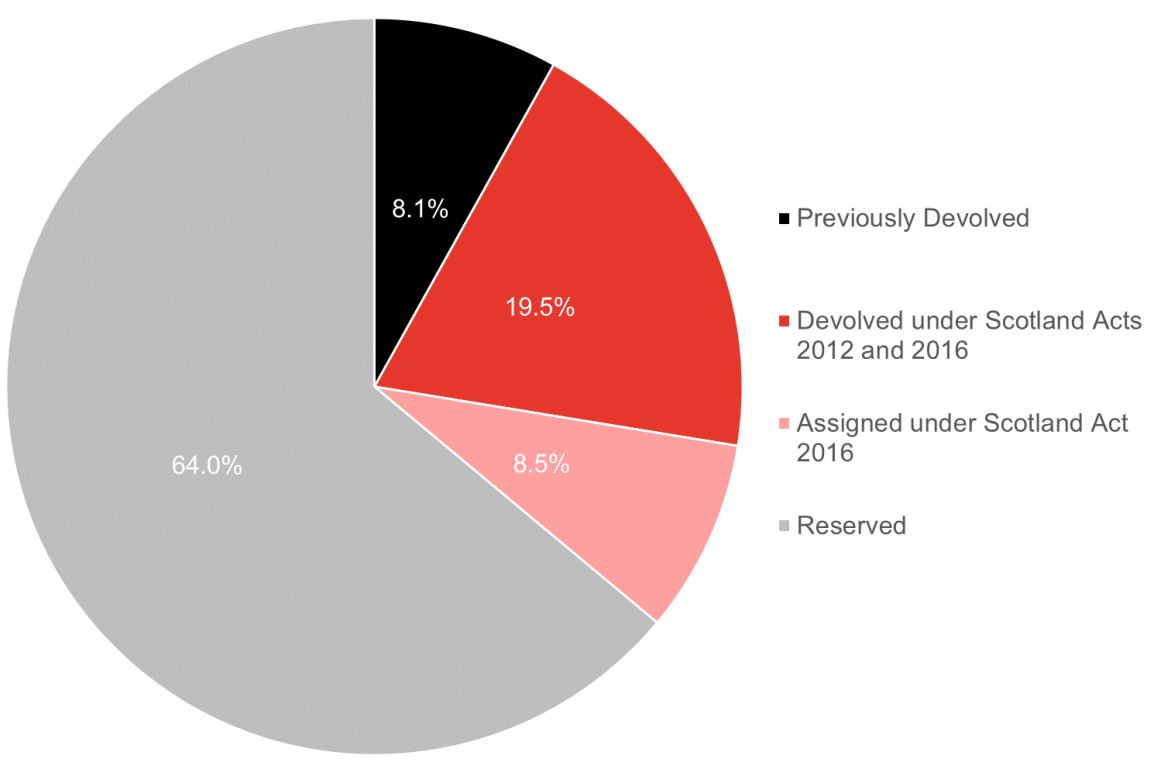

Source: GERS 2019-20 
Figure 8: Net fiscal position and North Sea Revenue, 1999/00 - 2019/20

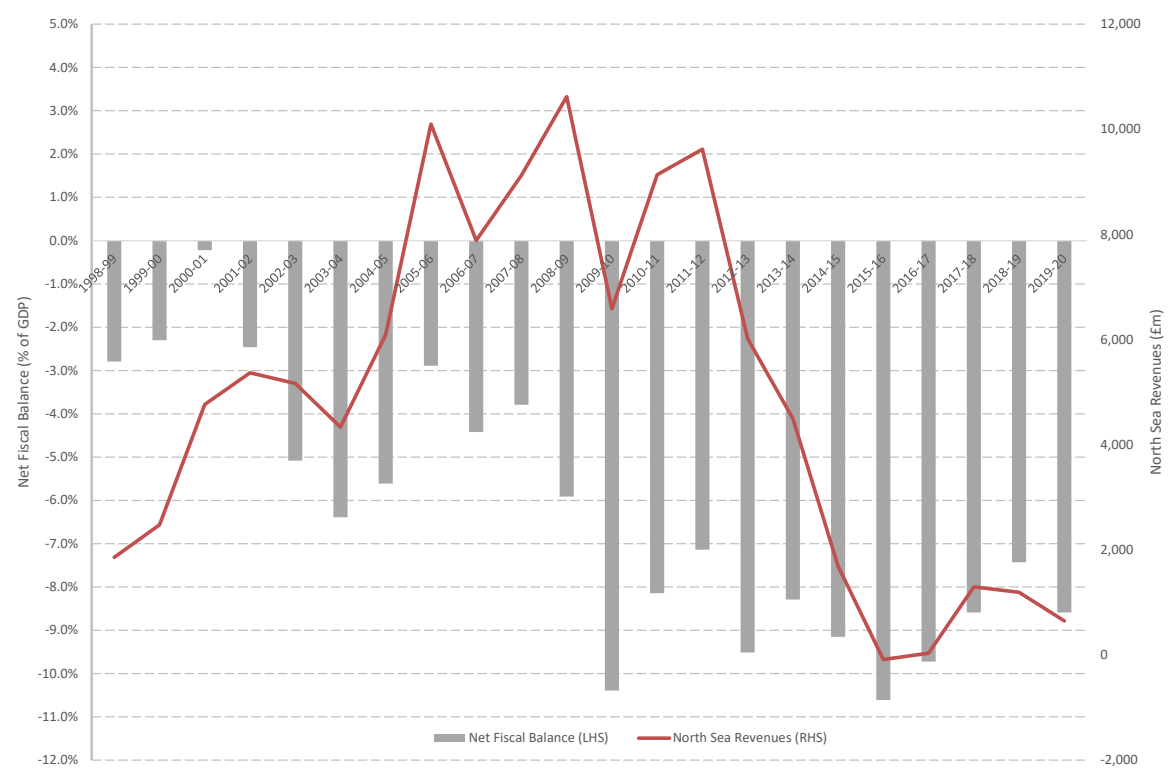

Source: GERS 2019-20 \& Authors' calculations

Figure 9: Total Revenue and Spending in Scotland, 2010/11 - 2019/20

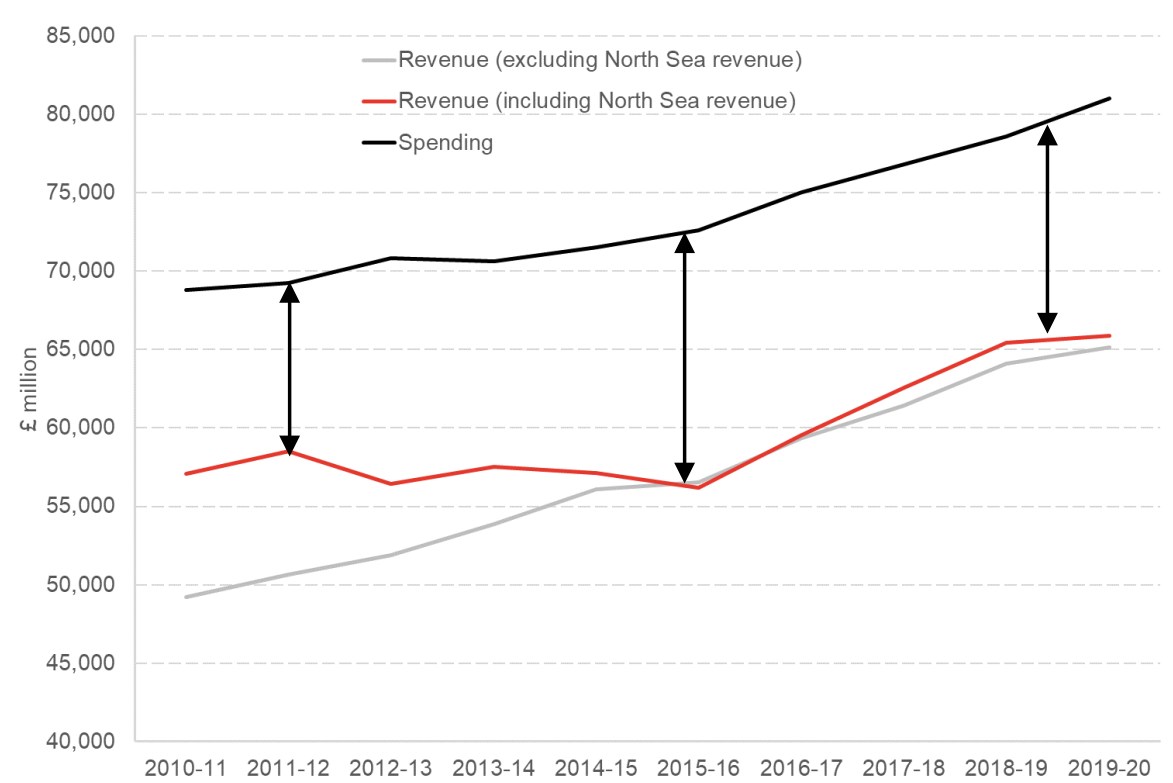

Source: GERS 2019-20 
Table 3: Estimated Net fiscal balance: UK NUTS 1 countries and regions 2018-19.

\begin{tabular}{|l|r|r|}
\hline Country/Region & $\begin{array}{r}\text { Net Fiscal Balance } \\
\text { (f millions) }\end{array}$ & $\begin{array}{r}\text { Net Fiscal Balance per head } \\
(\mathbf{f})\end{array}$ \\
\hline North East & $-10,803$ & $-4,064$ \\
\hline North West & $-20,275$ & $-2,780$ \\
\hline Yorkshire and the Humber & $-11,453$ & $-2,090$ \\
\hline East Midlands & $-6,357$ & $-1,323$ \\
\hline West Midlands & $-15,015$ & $-2,545$ \\
\hline East of England & 4,099 & 661 \\
\hline London & 38,754 & 4,350 \\
\hline South East & 21,691 & 2,375 \\
\hline South West & $-5,593$ & -999 \\
\hline England & $-4,954$ & -89 \\
\hline Wales & $-13,519$ & $-4,307$ \\
\hline Scotland & $-13,499$ & $-2,482$ \\
\hline Northern Ireland & $-9,401$ & $-4,996$ \\
\hline United Kingdom & $-41,372$ & -623 \\
\hline
\end{tabular}

Source: ONS, Country and Regional Public Sector Finances 